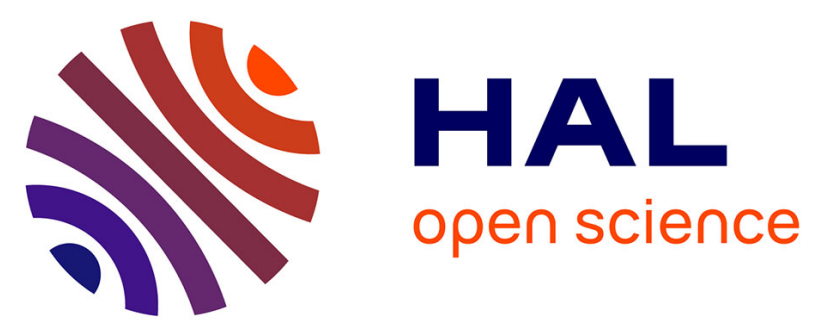

\title{
Aggregate stability of a crusted soil: differences between crust and sub-crust material, and consequences for interrill erodibility assessment. An example from the Loess Plateau of China
}

Baptiste Algayer, Bin Wang, Hocine Bourennane, Fenli Zheng, Odile Duval, Guifang Li, Yves Le Bissonnais, Frédéric Darboux

\section{To cite this version:}

Baptiste Algayer, Bin Wang, Hocine Bourennane, Fenli Zheng, Odile Duval, et al.. Aggregate stability of a crusted soil: differences between crust and sub-crust material, and consequences for interrill erodibility assessment. An example from the Loess Plateau of China. European Journal of Soil Science, 2014, 65 (3), pp.325-335. 10.1111/ejss.12134 . hal-01053425

\author{
HAL Id: hal-01053425 \\ https://hal.science/hal-01053425
}

Submitted on 28 May 2020

HAL is a multi-disciplinary open access archive for the deposit and dissemination of scientific research documents, whether they are published or not. The documents may come from teaching and research institutions in France or abroad, or from public or private research centers.
L'archive ouverte pluridisciplinaire HAL, est destinée au dépôt et à la diffusion de documents scientifiques de niveau recherche, publiés ou non, émanant des établissements d'enseignement et de recherche français ou étrangers, des laboratoires publics ou privés. 


\section{Aggregate stability of a crusted soil: differences between crust and}

2 sub-crust material, and consequences for interrill erodibility

3 assessment. An example from the Loess Plateau of China

4

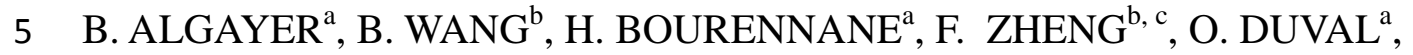

6 G. LI $^{\mathrm{c}}$, Y. LE BISSONNAIS ${ }^{\mathrm{d}}$, \& F. DARBOUX ${ }^{\mathrm{a}}$

7

8

9

$10{ }^{a}$ Institut National de la Recherche Agronomique (Inra), UR0272, Science du sol,

11 Centre de recherche Val de Loire, CS 40001, F-45075 Orléans Cedex 2, France,

$12{ }^{b}$ College of Resources and Environment (Northwest A\&F University), No. 3 Taicheng

13 Road, 712100, Yangling, Shaanxi, China, ${ }^{c}$ Institute of Soil and Water Conservation

14 (CAS), NO.26 Xinong Road, 712100, Yangling, Shaanxi, China, and ${ }^{d}$ INRA, UMR

15 LISAH (INRA-IRD-SupAgro), F-34060 Montpellier, France.

16

17 Correspondence: B. Algayer. Email: Baptiste.Algayer@orleans.inra.fr

18

19

20

21

22 Running title: Aggregate stability of a crusted soil 


\section{Summary}

Soil interrill erodibility is a key component of soil erosion models. However,

when using aggregate stability to assess soil erodibility, samples are usually collected

27 from the plough layer, while soil erosion occurs at the soil surface. Hence, the 28 potential changes in erodibility caused by crusting are ignored. Moreover, soil interrill

29 erodibility is still difficult to predict accurately. This lack of prediction means that

30 current erosion models use a constant erodibility value for a given soil, and thus do

31 not consider potential heterogeneity of erodibility. This study was conducted (i) to

32 assess the heterogeneity of aggregate stability for a crusted soil and (ii) to relate this

33 heterogeneity to the aggregate stability of the underlying material (sub-crust) and to

34 standard soil properties. A field study was conducted in a small area of the Loess

35 Plateau in China in which the crust and the sub-crust were sampled. Standard soil

36 properties (organic matter content, sand content, silt content, clay content, cation-

37 exchange capacity, $\mathrm{pH}$ in water, and water content at the time of sampling) were

38 measured as potential explanatory factors of aggregate stability. The results showed a

39 large heterogeneity in aggregate stability among the sites, even though the sites had

40 the same soil type. The mean weight diameter (MWD) of the crust varied between

410.33 and $2.04 \mathrm{~mm}$ while the MWD of the sub-crust varied between 0.23 and $1.42 \mathrm{~mm}$.

42 Soil texture and $\mathrm{pH}$ were very homogeneous among the sampling sites, whereas water

43 content, organic matter content and CEC varied more. Even though some correlations

44 existed (for example $r=0.57$ between the MWD for slow wetting test and organic

45 matter content), none of the standard soil properties was able to predict aggregate

46 stability accurately. The aggregate stability of the crust was significantly greater than

47 that of the sub-crust. The large differences in aggregate stability imply large 
48 differences in soil interrill erodibility. Because a single soil type was investigated, this

49 finding proves that erodibility can vary greatly in space even for a given soil type.

50 Soil interrill erodibility should be estimated from the exact material actually exposed

51 to erosive forces, the soil surface material. Using the sub-crust would have led to 52 greatly over-estimated erodibility and thus to a marked bias in erosion model 53 predictions.

\section{Résumé}

57 L'érodabilité inter-rigole est un paramètre clef des modèles d'érosion du sol. 58 Cependant, lorsque des tests de stabilité structurale sont utilisés pour évaluer 59 l'érodabilité, les mesures sont habituellement réalisées sur des échantillons prélevés 60 dans l'horizon labouré alors que l'érosion a lieu à la surface du sol. Ainsi, les 61 changements potentiels d'érodabilité causés par la formation de croûte sont ignorés. 62 De plus, l'érodabilité inter-rigole reste encore difficile à prédire avec précision. Ces 63 difficultés conduisent les modèles d'érosion à utiliser une érodabilité constante pour 64 un type de sol donné, et donc à ne pas considérer l'hétérogénéité potentielle de 65 l'érodabilité. Cette étude a été conduite pour (i) évaluer l'hétérogénéité de la stabilité structurale pour un sol encroûté et (ii) relier cette hétérogénéité à la stabilité 67 structurale du matériau sous-jacent (sous-croûte) et aux propriétés standards du sol. 68 Une étude de terrain a été réalisée sur un secteur de surface limitée du Plateau de 69 Lœss (Chine). Des échantillons provenant de la croûte et de la sous-croûte ont été 70 collectés. Les propriétés standards (teneur en carbone organique, teneurs en sable,

71 limon et argile, $\mathrm{CEC}, \mathrm{pH}$, et teneur en eau au prélèvement), ont été mesurées en tant 72 que facteurs explicatifs potentiels de la stabilité structurale. Les résultats ont montré 
73 une grande hétérogénéité de la stabilité structurale entre les différents sites alors que

74 ces derniers présentaient le même type de sol. Le MWD de la croûte variait entre 0,33

75 et 2,04 mm tandis que le MWD de la sous-croûte variait entre 0,23 et 1,42 $\mathrm{mm}$. La

76 texture du sol et le $\mathrm{pH}$ étaient très homogènes entre les sites étudiés, tandis que la

77 teneur en eau, la teneur en matière organique et la CEC variaient plus fortement. Bien

78 que certaines corrélations aient été identifiées (par exemple r=0.57 entre le MWD du

79 test à l'humectation lente et la teneur en carbone organique), aucune de ces propriétés

80 n'a permis de prédire précisément la stabilité structurale. La stabilité structurale de la

81 croûte était significativement supérieure à celle de la sous-croûte. Les grandes

82 différences de stabilité structurale mesurées impliquent des érodabilités très

83 contrastées. Comme un seul type de sol a été étudié, ce résultat prouve que

84 l'érodabilité peut être très variable spatialement pour un type de sol donné.

85 L'érodabilité inter-rigole du sol devrait être mesurée sur le matériau exact qui subit

86 l'érosion, c'est-à-dire le matériau de surface. L'utilisation du matériau sous-jacent

87 aurait engendré une forte surestimation de l'érodabilité et donc un biais important

88 dans les prédictions d'un modèle d'érosion.

90 Introduction

In the context of soil erosion by water, interrill erodibility corresponds to the 93 sensitivity of the surface material to detachment and transport by raindrop impacts 94 and by sheet flow. Accordingly, interrill erodibility is a key component in erosion 95 models (Gumiere et al., 2009; Wang et al., 2013). Currently, there is no unified 96 definition of erodibility and those proposed are qualitative: there is thus a need for 97 quantitative methods (Wang et al., 2013). 
Interrill erodibility can be estimated from standard soil properties such as soil texture or carbon content and using statistical functions (Alberts et al., 1995; Renard et al., 1997). Although such estimations are easy to carry out once the statistical

101 function has been established, they postulate that samples with similar standard soil 102 properties have similar erodibilities. Moreover, the ranges of validity of the statistical 103 functions (the textures and carbon contents for which these functions can be used) are 104 often limited and poorly known. Finally, erosion models typically use a single erodibility value for a given soil, hence postulating a small spatial heterogeneity of the erodibility (Renard et al., 1997; Jetten et al., 2003).

Another approach to characterize soil interrill erodibility is to measure aggregate stability in the laboratory (Le Bissonnais, 1996; Barthès \& Roose, 2002). Aggregate stability corresponds to the ability of an aggregate not to break up into smaller fragments. A large aggregate stability of the top-soil induces a strong resistance of the surface aggregates against breakdown, and thus induces less particle detachment and transport by raindrop impacts and by sheet flow (Le Bissonnais, 1996; Bajracharya \&

113 Lal, 1998). Hence, even though a few models use this soil property currently (LISEM, 114 De Roo et al., 1996), aggregate stability is considered as a proxy of soil interrill erodibility, with a poor aggregate stability corresponding to a large potential erodibility and vice versa (Barthès \& Roose, 2002; Gumiere et al., 2009).

117 The properties of a given soil may change over a period of a few weeks or months 118 because of crust development (Poesen, 1981; Bryan et al., 1989). In an agricultural 119 context, the soil surface evolves from a seedbed (loose surface layer composed of 120 clods and macro-aggregates) to successive stages of crusting that correspond to 121 different types of crust (Bresson \& Boiffin, 1990). The structural crust corresponds to 122 a thin surface layer where the micro-aggregates resulting from the breakdown of 
123 surface clods are sealed together, and the sedimentary crust corresponds to a compact

124 surface layer where the surface pores and micro-depressions are filled by small

125 fragments resulting from the erosion and sedimentation processes. The presence of a

126 crust can induce marked differences between the properties of the plough-layer and

127 the soil surface. Numerous studies show that the infiltration capacities can be very

128 different between the crust and the underlying material (e.g. Morin \& Van Winkel,

129 1996). However, only a few studies have addressed the effect of a crust on erodibility

130 (McIntyre, 1958; Poesen, 1981; Darboux \& Le Bissonnais, 2007). Most of the studies

131 using aggregate stability to assess erodibility are made with samples collected within

132 the plough layer (Bullock et al., 1988; Bajracharya \& Lal, 1998; Barthès \& Roose,

133 2002; Legout et al., 2005), notwithstanding that interrill erosion occurs at the soil

134 surface and thus depends directly on the erodibility of the crust and not on the

135 erodibility of the plough layer material. For a clay loam soil, Darboux \& Le

136 Bissonnais (2007) did not find significant differences in aggregate stability between a

137 structural crust and the seedbed material (without crust); but there were notable

138 differences in aggregate stability between a sedimentary crust and the seedbed

139 material (without crust). This finding led these researchers to conclude that

140 estimations of erodibility for material collected from the plough layer may be invalid

141 for the crust, resulting in a potential bias in the estimated erodibility. However, the

142 results of this laboratory experiment had limited application, and did not attempt to

143 assess the factors responsible for differences in aggregate stability, even though

144 numerous factors have previously been identified (Amézketa, 1999). In the present

145 work, a field study was conducted in a small area $(7.5 \mathrm{~km}$ radius $)$ of the Loess Plateau

146 of China. The crust and the underlying materials were sampled in areas designated for

147 different land uses. Aggregate stability was measured as a proxy of soil erodibility, 
148 along with standard soil properties known to be related to aggregate stability. We 149 wished to test the hypotheses that crusts developped from a given soil type show 150 different aggregate stabilities depending on the aggregate stability of the underlying 151 material and on the standard soil properties. The research objectives were (i) to assess 152 the heterogeneity of aggregate stability of crusted Luvisols within an area presenting a 153 small spatial extent and (ii) to relate this heterogeneity to the aggregate stability of the 154 underlying material and to the standard soil properties. The consequences for 155 erodibility assessment and erosion modeling are discussed.

157 Materials and methods

159 Sampling sites

160 The Chinese Loess Plateau (northwest China) is recognized as the largest deposit of 161 loess in the world. Silt particles resulting from wind erosion at the Tibetan Plateau and 162 the Gobi desert have accumulated to an average thickness of $150 \mathrm{~m}$. The silt loam 163 soils that developed on this substrate are very homogeneous in both texture and 164 chemical properties and are recognized to be very sensitive to erosion (Zheng, 2005). 165 The experimental area was located in the Ziwuling area, in the hilly-gully region of 166 the Loess Plateau (Figure 1). Altitude of the sampling sites varied between 1100 and $1671300 \mathrm{~m}$ with an average annual temperature of $9^{\circ} \mathrm{C}$ and average annual precipitation 168 of $577 \mathrm{~mm}$. Soil samples were collected on seven field sites, selected in order to 169 present the same soil type (silt loam Luvisols, WRB, developed on loessial material) 170 but with different land uses, erosion conditions and environmental conditions such as 171 altitude, slope position and orientation (Table 1). The sites (A, B, C and D) were 172 geographically close together (located within a $7.5 \mathrm{~km}$ radius) (Figure 1 ). There were 
173 four sub-sites at D (D1, D2, D3 and D4) which were located along a 200-m long

174 eroded hill slope. Table 1 provides details of the various land uses and locations.

175

\section{Sampling method}

177 Sampling was performed in September 2009 over a period of three consecutive days,

178 beginning four days after the last previous rain event. For each site (A, B, C, D1, D2, 179 D3 and D4), five plots (one square meter each) were defined to collect samples in order to take into account the spatial heterogeneity within each site. Prior to sampling,

181 the soil surface was described, and the crust type was identified (Bresson \& Boiffin, 182 1990; Belnap et al., 2008). The soil surfaces had no obvious mosses or lichens and 183 had a light colour, indicating little cyanobacterial development (Belnap et al., 2008).

Paired samples (crust and underlying material) were collected from each plot at each site so that the crust was collected separately from the underlying material (hereafter referred to as 'sub-crust'). All of the sites had a structural crust, but only site $\mathrm{C}$ had both structural and sedimentary crust. Therefore, only structural crust is considered hereafter. Because the lower depth of the structural crust was indistinct, a thickness of approximately $5 \mathrm{~mm}$ was considered to be the limit. The sub-crust was defined as the soil material between -1 and $-5 \mathrm{~cm}$ from the soil surface. In all cases, three-to-five $\mathrm{cm}$ samples were collected using a sharp knife to cut through the material without affecting its structure. Soil samples from the crust and sub-crust were divided into five sub-samples in order to measure aggregate stability, organic matter content, $\mathrm{CEC}, \mathrm{pH}$ and soil texture.

\section{Measurements}


Aggregate stability Samples were oven-dried at $40^{\circ} \mathrm{C}$ over two days and stored in a cold room at $4^{\circ} \mathrm{C}$ for fifteen days before measurements. Aggregate stability was measured using a slightly modified version of Le Bissonnais' method (Le Bissonnais, 1996; ISO/DIS 10930, 2012), where air-dried samples from both crust and sub-crust were cut into $2-5 \mathrm{~mm}$ fragments with a sharp knife.

The three stability tests of Le Bissonnais (1996) (fast wetting, slow wetting and stirring) were designed to reproduce the processes involved in crust formation and interrill erosion (slaking, differential clay swelling and mechanical breakdown).

Results of each test can be investigated separately to analyse the resistance of the material against each process. Because the three processes occur often simultaneously: the three MWD resulting from the three tests are commonly averaged.

Five-g sub-samples were dried at $40^{\circ} \mathrm{C}$ for 24 hours before the application of a 210 test, and each test was replicated twice (instead of three times as in the original 211 method). After the tests, the resulting fragments were sieved in ethanol. The results 212 are presented using the mean weighted diameter (MWD). Each MWD corresponds to 213 one of five classes of stability: MWD $>2 \mathrm{~mm}$ corresponds to very stable material 214 (very weak erodibility), between 2 and $1.3 \mathrm{~mm}$ corresponds to stable material (weak 215 erodibility), between 1.3 and $0.8 \mathrm{~mm}$ corresponds to median stability (median 216 erodibility), between 0.8 and $0.4 \mathrm{~mm}$ corresponds to unstable material (strong 217 erodibility), and $<0.4 \mathrm{~mm}$ corresponds to very weak stability (very strong erodibility) 218 (Le Bissonnais, 1996).

220 Standard soil properties Standard soil properties were measured to explain 221 differences in aggregate stability between the sites and between the crust and sub- 
crust. These were gravimetric water content, organic matter content, clay content, silt content, sand content, CEC and $\mathrm{pH}$. Relationships between these variables and

224 aggregate stability have frequently been reported in the literature (Wischmeier \& 225 Mannering, 1969; Tisdall \& Oades, 1982; Amézketa, 1999; Zhang \& Horn, 2001). 226 Hence, these variables could be assumed to be suitable explanatory factors for the differences in aggregate stability between the crust and sub-crust materials of a given site and also between sites.

229 Clay, silt and sand contents were measured by laser diffraction granulometry, 230 (Loizeau et al.,1994), with a Mastersizer 2000 (Malvern Instruments Ltd, Malvern, 231 UK). Soil organic matter content was measured with the Walkey \& Black (1934) 232 method, cation-exchange capacity (CEC) with the ammonium rapid method 233 (Mackenzie, 1951), and $\mathrm{pH}$ with a 1:2.5 soil:water ratio and a pH meter. Gravimetric 234 water content was measured at the time of sampling: 10-g sub-samples were dried at $235105^{\circ} \mathrm{C}$ over 48 hours. Measurements were performed on soil bulk samples for both 236 crust and sub-crust materials. Each measurement was replicated twice.

238 Statistical analyses

239 Statistical analyses were performed using version 2.9.2 of software R (R Development 240 Core Team, 2011). To avoid the assumption of normality of samples required for the 241 use of parametric tests, a non-parametric test (Wilcoxon test) was used to compare the 242 MWD and the standard soil properties of crust and sub-crust samples. We considered 243 a significant threshold of 5\%. The heterogeneity (dispersion) of the soil properties was 244 quantified using the coefficient of variation, which is a normalized measure of 245 dispersion. Linear correlation analyses (Pearson's coefficient) were performed to 246 quantify the relationships between the standard soil properties and aggregate stability. 
247 To model MWD according to the soil properties, in other words to quantify the 248 proportion of MWD (dependent variable) variability which is explained by 249 independent variables, multiple regression analyses were conducted.

\section{Results}

Heterogeneity of the aggregate stability For all the sampling sites, and for both crust and sub-crust, MWD was the largest for the slow wetting test $(1.47$ and $0.97 \mathrm{~mm}$ for the crust and sub-crust, respectively) and the least for the fast wetting test (0.98 and $0.36 \mathrm{~mm}$ for the crust and sub-crust, respectively) (Table 2).

257 When the mean of the three stability tests is considered, the MWD of the crust varied 258 among the sites between 0.33 and $2.04 \mathrm{~mm}$, with a coefficient of variation of 0.37 259 (Table 2). For crust material and for each stability tests, sites A (cultivated maize field) and D1 (Ziwuling experimental station, interrill area) had the largest MWD while site $\mathrm{C}$ (cultivated radish) had the smallest (Figure 2).

With the sub-crust, and again considering the mean of the three stability tests, the MWD varied between 0.23 and $1.42 \mathrm{~mm}$, with a coefficient of variation of 0.47 (Table 2). For all the stability tests on these samples, site D1 had the largest MWD and site $\mathrm{C}$ had the smallest (Figure 2). Among the sites, the coefficients of variations were larger for the sub-crust samples than for the crust samples, except for the stirring

267 test which had the same coefficient of variation (Table 2). For each site, samples were 268 collected from five plots to consider intra-site heterogeneity. Considering the mean of 269 the three stability tests, the intra-site coefficient of variations for the five plots taken at 270 each site were larger for the sub-crust than for the corresponding crust samples for 271 sites A, D1, D2, D3 and D4. 
273 Comparison of aggregate stability for paired crust and sub-crust samples

274 The aggregate stability of the crust was significantly different from that of the 275 underlying material $\left(P=2 \cdot 10^{-10}\right.$ for the mean of the three stability tests). For most of 276 the paired samples, the aggregate stability of the crust was greater than that of the 277 corresponding sub-crust, and the sub-crust samples were never more stable than their 278 corresponding crust (Figure 2). The difference in aggregate stability between crust and 279 sub-crust varied with the stability test. The fast wetting test had the the largest 280 differences in MWD between crust and sub-crust (0.62 mm, Table 3). In order to 281 study the relationships between the MWD of the crust and the MWD of the sub-crust material, a correlation analysis was undertaken for each aggregate stability test and for

283 the mean of the three tests. The largest correlation coefficient $\left(r=0.69, P=5.10^{-6}\right.$ 284 significant) was found between the MWD of the crust and that of the sub-crust for the 285 slow wetting test. The correlation coefficients were 0.43 for the fast wetting test $(P=$ 2860.009 , significant $), 0.48$ for the stirring test $(P=0.003$, significant $)$ and 0.59 for the 287 mean of the three tests $\left(P=2.10^{-4}\right.$, significant $)$. However, these correlation 288 coefficients were greatly influenced by the very small MWD of site C. Without site C, 289 the correlation coefficients were only 0.52 for the slow wetting $(P=0.003$, 290 significant), 0.20 for the fast wetting $(P=0.30),-0.06$ for the stirring test $(P=0.75)$ 291 and 0.28 for the mean of the three tests $(P=0.14)$. The difference in aggregate 292 stability between a crust and its sub-crust showed the crust was always more stable. 293 The amplitude of this difference varied greatly both for a given site and among the 294 sites (Table 3). For example, for the mean of the three tests, the inter-site coefficient 295 of variation was 0.60 (Table 3a), whereas it ranged from 0.16 (site D4) to 0.90 296 (site D1) (Table 3b). 
Variability of standard soil properties

299 All samples had silt content between 65.5 and $73.1 \%$ and clay content between 10.0 300 and $14.4 \%$ (Figure 3 ) and thus belonged to the silt loam texture class (Soil Survey 301 Division Staff, 1993). Clay content had little variability between the sampling sites. 302 Silt content and sand content presented larger differences between sites, but their 303 inter-site variability was small.

304 There were large differences in gravimetric water contents between crust and sub305 crust. The water content of sub-crust was larger than that of crust whatever the site.

306 Crust water content varied between $0.8 \%$ (site C) and $11.7 \%$ (site D4) while sub-crust 307 water content varied between 10.8\% (site D2) and 14.9\% (site D4) (Figure 4d). Crust 308 water content varied significantly between sites while sub-crust water content did not 309 differ significantly among the sites (Figure 4d).

310 The organic matter content varied between $0.7 \%$ (site D4) and $1.9 \%$ (site B)

311 (Figure 4a). The CEC varied between $16.6 \mathrm{cmol} \mathrm{kg}^{-1}$ (site C) and $27.5 \mathrm{cmol} \mathrm{kg}^{-1}$ 312 (site A) (Figure 4b). The organic matter content and CEC varied significantly between 313 sites. The $\mathrm{pH}$, which ranged between 8.3 and 8.6, did not differ significantly between 314 the sites (Figure 4c).

315 At both intra- and inter-site scales, the percentages of clay, silt and sand 316 (Figure 3), organic matter content, $\mathrm{CEC}$ and $\mathrm{pH}$ (Figure 4) did not differ significantly 317 between a crust and its corresponding sub-crust.

319 Relationship between standard soil properties and aggregate stability

320 A correlation analysis was performed between the aggregate stability (MWD) and the 321 soil properties assumed to be potential explanatory factors (Table 4). This analysis 

cases, the largest correlation coefficients were found between the MWD of the slow

324 wetting test $\left(0.57, P=3.10^{-4}\right.$, significant $)$ and the organic matter content $(0.56, P=$ $3254.10^{-4}$, significant).

326 Clay, silt and sand contents were not significantly correlated with any of the 327 MWD values, either for the crust and sub-crust samples. For the crust, water content, organic matter content and CEC were significantly correlated with the MWD whatever the stability test (Table 4a). For the sub-crust, organic matter content, CEC and $\mathrm{pH}$ correlated significantly with MWD, except that organic matter content did not correlate significantly with MWD for the stirring test, and $\mathrm{pH}$ did not correlate with MWD for slow wetting test (Table 4b).

A multiple regression analysis was performed using the soil properties (organic matter content, $\mathrm{CEC}$, water content and $\mathrm{pH}$ ) wich were significantly correlated to aggregate stability. For the crust, among all the combinations tested the best regression was found for the mean MWD of the three tests as the dependent variable and the organic carbon content and CEC as explanatory variables:

$$
\mathrm{MWD}_{\text {mean }}(\mathrm{mm})=0.39( \pm 0.15) \times \mathrm{SOM} \quad(\%)+0.06( \pm 0.02) \times \mathrm{CEC} \quad\left(\mathrm{cmol}^{\mathrm{kg}} \mathrm{kg}^{-1}\right)-
$$

340 (the number in parenthesis is the standard error).

341 The coefficient of determination $\left(R^{2}\right)$ was 0.38 . The residual standard error for the 342 estimated MWD was $0.36 \mathrm{~mm}$ at the $95 \%$ confidence interval. However, because 343 organic matter content and CEC are significantly correlated, the relevance of the 344 proposed relationship is questionable. When CEC is removed from the relationship, 345 the model explained only $25 \%$ of the variance of the MWD for the mean of the three 346 tests. 
For the sub-crust, among all the tested combinations, the most statistically

meaningful regression was found between MWD of the slow wetting test and organic matter content and $\mathrm{pH}$ :

$$
\operatorname{MWD}_{\mathrm{SW}}(\mathrm{mm})=0.69( \pm 0.17) \times \mathrm{SOM}(\%)+1.15( \pm 0.44) \times \mathrm{pH}-9.62( \pm 3.70) .
$$

(the number in parenthesis is the standard error). The coefficient of determination $\left(R^{2}\right)$ was 0.40 . The residual standard error for the estimated MWD was $0.43 \mathrm{~mm}$ at the $95 \%$ confidence interval.

In order to link the differences in MWD between the crust and the sub-crust materials to the soil properties further, linear correlation analysis was performed (Table 5). Potential explanatory factors were the soil properties as before but also the difference between the crust and the sub-crust for a given soil property.

Generally, the differences in stability between the crust and the sub-crust materials were positively correlated with (i) the crust organic matter content and the difference in carbon content between crust and sub-crust, (ii) the crust and sub-crust CEC and (iii) the crust water content. In addition, the differences in stability between the crust and the sub-crust materials were generally negatively correlated with the crust silt content. A multiple regression analysis was performed using the difference in aggregate stability between the crust and sub-crust materials as dependent variable and the soil properties and the differences between each property for the crust and sub-crust as explanatory variables. No statistically meaningful relationship was found.

\section{Discussion}


373 stability between crust and its underlying material. However, differences in aggregate

374 stability as a function of the crusting stage were investigated by McIntyre (1958) and

375 more recently by Darboux \& Le Bissonnais (2007). Using simulated rainfall in the 376 field, McIntyre (1958) showed that crusting decreased the splash rate on sandy loams, 377 concluding that the crust formation processes increased the resistance of soil surface 378 against the breakdown induced by the raindrop impacts. This observation concurs 379 with the results of the stirring test in the present study, where crust had larger MWD 380 than its underlying material for most of the sites (Figure 2c). The same observations 381 were found for the other stability tests (Figure 2b, 2c). Darboux \& Le Bissonnais 382 (2007) showed different results in a laboratory experiment. They measured the aggregate stability of a seedbed (non-crusted, initial material), a structural crust and a sedimentary crust, and showed that the stability of structural crust was similar to that of the seedbed. In the present study, the aggregate stability of the structural crust was usually very different from the aggregate stability of the sub-crust irrespective of the sampling site and the stability test. The differences between the results of these two studies may lie in the experimental conditions. Darboux \& Le Bissonnais experiment (2007) used a soil with a different texture (11\% clay, 58\% silt and $31 \%$ sand) and well-controlled experimental conditions in a laboratory. The structural crust was 391 formed very rapidly: starting from a seedbed (non-crusted material), they applied a 392 single and intense simulated rain $\left(30 \mathrm{~mm} \cdot \mathrm{h}^{-1}\right)$, and obtained a structural crust after 393 only six minutes of rain. Moreover, samples were collected quickly after the rain 394 ended. In our field conditions, crust formation was probably a more gradual and 395 discontinuous process, depending on the duration and intensity of successive rainfalls. 
The present crust samples must therefore have gone through numerous cycles of wetting and drying that could lead to additional consolidation.

The amplitude of the difference in aggregate stability between crust and sub-crust varied according to the stability test (Table 3a). The fast wetting test was designed to reproduce the processes of slaking: during rapid wetting, the compression of air entrapped inside the aggregate ruptures the inter-particle bonds within the aggregate and producing small fragments leading to a small MWD (Le Bissonnais, 1996). Subcrust material was very sensitive to slaking, leading to the smallest MWD, and to the largest differences in MWD between crust and sub-crust (Figure 2a). The amplitudes of difference were least for the differential swelling process involved in the slow wetting test and for the kinetic energy involved in the stirring test (Table 3a, Figure 2).

407 Thus, the fast wetting test was the best discriminator between the crust and sub-crust MWD.

For a given site, water content at the time of sampling was the only variable showing significative differences between crust and sub-crust (Figure 4). However, none of the measured standard soil properties was able to explain the differences in

412 aggregate stability between crust and sub-crust. The crust is directly exposed to 413 atmospheric conditions and may be submitted to a larger amplitude of wetting and 414 drying cycles than the sub-crust. As wetting and drying cycles are an important factor 415 of aggregate stability variation (Cosentino et al., 2006), we can hypothesize that 416 difference in hydric history between crust and sub-crust may explain some of the 417 difference in aggregate stability between these materials. Water content at the time of 418 sampling did not give information about the hydric history of the soil, and thus, could 419 not explain the differences in aggregate stability between crust and sub-crust. The 420 differences may be explained by other variables. Because the crust and sub-crust 
421 originated from the same initial material (a seedbed for the cultivated fields), the

422 differences in stability result necessarily from the crust formation processes. In

423 addition, the presence of carbonates and their crystallization through wetting and

424 drying cycles may also play a role in the crust reinforcement (Fernandez-Ugalde et 425 al., 2011). Those possibilities indicate a need for a time-monitoring of aggregate 426 stability and other variables in both the crust and sub-crust.

Aggregate stability varied greatly even for sites located on the same soil type within a

429 small area

430 In the present study, standard soil properties were not dominant factors controlling 431 aggregate stability. Water content, organic matter content and CEC varied 432 significantly among the sites (Figure 4). Because these variables are known to be 433 related to aggregate stability (Wischmeier \& Mannering, 1969; Tisdall \& Oades, 434 1982; Amézketa, 1999; Zhang \& Horn, 2001), it might have been expected that the 435 variability in aggregate stability could be explained by these properties. None of these 436 variables (or their combination) was able to satisfactorily predict the aggregate 437 stability of the crust or sub-crust. At best, only $40 \%$ of the variability could be 438 explained and this had a residual standard error of approximately $0.4 \mathrm{~mm}$. Hence, the 439 predicted MWD could be wrong by as much as two stability classes (out of five 440 stability classes) (Figure 2). Consequently, these relationships have no practical use 441 for prediction, and their use would probably lead to large flaws in the interpretations.

442 Land use and site environmental conditions may have caused the differences in 443 stability among the sites without affecting the standard soil properties. Variables 444 known to affect aggregate stability, but not commonly noted, include tillage, crop 445 management or mulching through their effect on microbial activity and soil water 
content (Amézketa, 1999). Altitude, slope position and orientation influence local

447 climate which can affect aggregate stability through soil hydric history (Amézketa,

448 1999; Cosentino et al., 2006). The current experimental design did not allow us to

449 study precisely the influence of topography or location. However, we can note that

450 sites A and D1 that had the largest MWD for both crust and sub-crust were located on

451 the lowest slopes. Even more than hydric history, topography can affect flow and

452 transport history of the material which in return affects aggregate stability (Amézkéta,

453 1999). In future studies, variables such as the organic matter quality, microbial

454 activity, wetting-drying cycles and topography may need to be considered.

455 The heterogeneity of the aggregate stability measured in the crust samples was 456 less than that measured in the sub-crust samples. This finding was consistent in the 457 inter-site comparison and often observed in the intra-site comparison. The crust had 458 larger MWD on average and larger standard deviation than the sub-crust (Table 2). As 459 the observed aggregate system is physically constrained by full dispersion of the 460 particles (the MWD of a fully dispersed loamy soil may be around $0.2 \mathrm{~mm}$ ), it may 461 have been expected that CV values would decrease with increasing MWD. However, 462 our analysis did not identify correlations between the standard deviation and the mean 463 MWD, nor negative correlations between the mean MWD and the CV. Hence, the 464 smaller heterogeneity of crust aggregate stability than of that of the sub-crust may not 465 be related to the $\mathrm{CV}$ calculation. The development of the crust could have decreased 466 the spatial heterogeneity of aggregate stability. This assumption has to be examined in 467 future studies. 
When used for erodibility assessment, aggregate stability is usually measured in the

471 sub-crust material (Bullock et al., 1988; Bajracharya \& Lal, 1998; Barthès \& Roose,

472 2002; Legout et al., 2005). The finding that the crust is generally less erodible than

473 the sub-crust strongly suggests that erodibility should be assessed on the material

474 actually exposed to erosive forces: the soil surface. The common practice of using the

475 underlying material, instead of the crust, would cause an over-estimate by at least one

476 erodibility class in $60 \%$ of cases and by at least two erodibility classes in $30 \%$ of

477 cases of our soil (Figure 2).

478 In erosion models, erodibility can be assessed with soil standard properties such as

479 soil texture and organic matter content through statistical functions (Alberts et al., 480 1995; Renard et al., 1997). Such an approach assumes that samples collected from the 481 same soil type have similar erodibilities (Gumiere et al., 2009). Because a single soil 482 type was investigated in the present study, a similar erodibility would have been 483 expected. This was clearly not the case. This finding underlines the large uncertainty 484 in the prediction of erodibility when assessed using standard soil properties. Currently, 485 parameterization of erosion models sets a single erodibility value for a given soil and 486 thus does not consider the variability of erodibility within a given soil. This over487 simplification could explain part of the large inaccuracy in the predicted results of 488 erosion models (Jetten et al., 2003). Comparisons between the seven sites showed that 489 the heterogeneity of the crust was less than that of the sub-crust. Using crust samples 490 for erodibility assessment, would decrease the heterogeneity of the mapped erodibility 491 (although this heterogeneity would remain large).

\section{Conclusions}


495 Crust showed a greater aggregate stability than its underlying material. This finding

496 emphasizes the importance of estimating soil interrill erodibility on the soil surface

497 material. On a crusted soil, the use of material collected from the plough layer may

498 lead to greatly over-estimated erodibility and thus bias the results of the erosion

499 models. The large heterogeneity in aggregate stability among sites proves that 500 erodibility can greatly vary in space, even when considering a small test area and a 501 single soil type. From the present study, we conclude that interrill erodibility 502 assessment should ideally be performed with a large sampling density, which could be 503 impractical, leaving the construction of a sound erodibility map currently 504 unattainable. The fact that standard soil properties were not able to accurately predict 505 the observed differences in aggregate stability lead us to suggest investigating other 506 variables such as (i) the soil hydric history linked to local climatic conditions, (ii) 507 environmental factors such as topography and (iii) the physical processes involved in 508 crust formation. Factors that affect the erodibility of the soil surface should be better 509 understood so that reliable erodibility maps can be produced from a reasonably small 510 set of measurements.

\section{Acknowledgments}

514 The content of the paper greatly benefited from the reviewer's comments. This 515 research was supported by the French Ministry of Foreign Affairs through a Hubert 516 Curien grant (PFCC 2009-2010 \#20919ZC) and by the National Basic Research 517 Program of China (Grant No. 2007CB407201). 
Alberts, E. E., Nearing, M. A., Weltz, M. A., Risse, L. M., Pearson, F. B., Zhang, X. C., et al. 1995. Soil component. In: USDA - Water Erosion Prediction Project. Hillslope Profile and Watershed Model Documentation. (eds D. C. Flanagan \& M. A. Nearing), pp. 7.1-7.47. USDA-ARS, National Soil Erosion Research Laboratory, West Lafayette, IN, USA.

Amézketa, E. 1999. Soil aggregate stability: a review. Journal of Sustainable Agriculture, 14, 83-151.

Bajracharya, R. M. \& Lal, R. 1998. Crusting effects on erosion processes under simulated rainfall on a tropical Alfisol. Hydrological Processes, 12, 1927-1938.

Barthès, B. \& Roose, E. 2002. Aggregate stability as an indicator of soil susceptibility

Bullock, M. S., Kemper, W. D. \& Nelson, S. D. 1988. Soil cohesion as affected by

Belnap, J., Phillips, S. L., Witwicki, D. L. \& Miller, M. E. 2008. Visually assessing the level of development and soil surface stability of cyanobacterially dominated biological soil crusts. Journal of Arid Environments, 72, 1257-1264.

Bresson, L. \& Boiffin, J. 1990. Morphological characterization of soil crust development stages on an experimental field. Geoderma, 47, 301-325.

Bryan, R. B., Gover, G. \& Poesen, J. 1989. The concept of soil erodibility and some problems of assessment and application. Catena, 16, 393-412. freezing, water content, time and tillage. Soil Science Society of America Journal, 52, 770-776. 
542 Cosentino, D., Chenu, C. \& Le Bissonnais, Y. 2006. Aggregate stability and microbial 543 community dynamics under wetting-drying cycles in a siltloam soil. Soil Biology $544 \quad$ and Biochemistry, 38, 2053-2052.

545 Darboux, F. \& Le Bissonnais, Y. 2007. Changes in structural stability with soil surface 546 crusting: consequences for erodibility estimation. European Journal of Soil 547 Science, 58, 1107-1114.

548 De Roo, A. P. J., Wesseling, C. G. \& Ritsema, C. J. 1996. LISEM: a single-event, 549 physically based hydrological and soil erosion model for drainage basins. I: 550 Theory, input and output. Hydrological Processes, 10, 1107-1117.

551 Fernandez-Ugalde, O., Virto, I., Barre, P., Gartzia-Bengoetxea, N., Enrique, A., Imaz, 552 M.J. et al. (2011) Effect of carbonates on the hierarchical model of aggregation in calcareous semi-arid Mediterranean soils. Geoderma, 164, 203-214.

Gumiere, S. J., Le Bissonnais, Y. \& Raclot, D. 2009. Soil resistance to interrill erosion: model parameterization and sensitivity. Catena, 77, 274-284.

ISO/DIS 10930. 2012. Soil quality - Measurement of the stability of soil aggregates subjected to the action of water. International Organization for Standardization, Geneva, Switzerland.

Jetten, V., Govers, G. \& Hessel, R. 2003. Erosion models: quality of spatial predictions. Hydrological Processes, 17, 887-900.

Le Bissonnais, Y. 1996. Aggregate stability and assessment of soil crustability and erodibility: I. Theory and methodology. European Journal of Soil Science. 47, 425-437.

Legout, C., Leguédois, S. \& Le Bissonnais, Y. 2005. Aggregate breakdown dynamics under rainfall compared with aggregate stability measurements. European Journal of Soil Science, 56, 225-238. 
Loizeau, J.L., Arbouille, D., Santiago, S. \& Vernet, J-P. 1994. Evaluation of a wide range laser diffraction grain size analyser for use with sediments. Sedimentology, 41, 353-361.

Mackenzie, R. C. 1951. A micromethod for determination of cation-exchange capacity of clay. Journal of Colloid Science, 6, 219-222.

McIntyre, D. S. 1958. Soil splash and the formation of surface crusts by raindrop impact. Soil Science, 85, 261-266.

Morin, J. \& van Winkel, J. 1996. The effect of raindrop impact and sheet erosion on infiltration rate and crust formation. Soil Science Society of America Journal, 60, 1223-1227.

Poesen, J. 1981. Rainwash experiments on the erodibility of loose sediments. Earth Surface Processes \&Landforms, 6, 285-307.

R Development Core Team. 2011. R: A Language and Environment for Statistical Computing. R Foundation for Statistical Computing. At: http://www.R-project.org

Renard, K. G., Foster, G. R., Weesies, G. A., McCool, D. K. \& Yoder, D. C. 1997. Predicting Soil Erosion by Water: a Guide to Conservation Planning with the Revised Universal Soil Loss Equation (RUSLE). Agricultural Handbook 703, United States Department of Agriculture - U.S. Gov. Print. Office, Washington, DC, USA.

Soil Survey Division Staff. 1993. Soil Survey Manual. Soil conservation Service. United State Departement of Agriculture. Handbook 18. At: http://soils.usda.gov/technical/manual/

Tisdall, J. M. \& Oades, J. M. 1982. Organic matter and water stable aggregate in soils. Journal of Soil Science, 33, 141-163. 
591 Walkey, A. \& Black, I. A. 1934. An examination of Degtjareff method for determining 592 soil organic matter and a proposed modification of the chromic acid titration 593 method. Soil Science, 37, 29-37.

594 Wang, B., Zheng, F., Darboux, F. \& Römkens, M. J. M. 2013. Soil erodibility for 595 water erosion. A perspective and Chinese experience. Geomorphology, 187, 1-10.

596 Wischmeier, W. H. \& Mannering, J. V. 1969. Relation of soil properties to its 597 erodibility. Soil Science Society of America Proceedings, 33, 131-137.

598 Zhang, B. \& Horn, R. 2001. Mechanisms of aggregate stabilization on Ultisols from 599 sub tropical China. Geoderma, 99, 123-145.

600 Zheng, F. L. 2005. Effect of accelerated soil erosion on soil nutrient loss after 601 deforestation on the Loess Plateau. Pedosphere, 15, 707-715. 
Table 1 Site locations and land uses

\begin{tabular}{|c|c|c|c|c|c|}
\hline Site & $\begin{array}{l}\text { Geographic location } \\
\text { (latitude; longitude) }\end{array}$ & Land use and slope position & $\begin{array}{l}\text { Altitude } \\
\qquad / \mathbf{m}\end{array}$ & Orientation & $\begin{array}{c}\text { Slope } \\
\text { gradient } \\
\text { (field scale) }\end{array}$ \\
\hline $\mathrm{A}$ & $36^{\circ} 03.888^{\prime} \mathrm{N} ; 109^{\circ} 12.621^{\prime} \mathrm{E}$ & Cultivated maize field, upslope & 1053 & $\mathrm{E}$ & $5^{\circ}-10^{\circ}$ \\
\hline $\mathrm{B}$ & $36^{\circ} 03.874^{\prime} \mathrm{N} ; 109^{\circ} 12.675^{\prime} \mathrm{E}$ & Apple orchard, shoulder of a terrace & 1118 & SW & $5^{\circ}-30^{\circ}$ \\
\hline $\mathrm{C}$ & $36^{\circ} 04.227^{\prime} \mathrm{N} ; 109^{\circ} 11.226^{\prime} \mathrm{E}$ & $\begin{array}{l}\text { Cultivated radish crop, middle slope, } \\
\text { sampling in ridges and furrows }\end{array}$ & 1206 & SE & $5^{\circ}-13^{\circ}$ \\
\hline D1 & $36^{\circ} 05.149^{\prime} \mathrm{N} ; 109^{\circ} 8.958^{\prime} \mathrm{E}$ & $\begin{array}{l}\text { Ziwuling experimental station, bare soil, } \\
\text { upslope, interrill area }\end{array}$ & 1270 & SW & $5^{\circ}-10^{\circ}$ \\
\hline D2 & $36^{\circ} 05.431^{\prime} \mathrm{N} ; 109^{\circ} 8.951^{\prime} \mathrm{E}$ & $\begin{array}{l}\text { Ziwuling experimental station, bare soil, } \\
\text { mid-slope, rill area }\end{array}$ & 1245 & SW & $30^{\circ}-35^{\circ}$ \\
\hline D3 & $36^{\circ} 05.450^{\prime} \mathrm{N} ; 109^{\circ} 8.947^{\prime} \mathrm{E}$ & $\begin{array}{l}\text { Ziwuling experimental station, bare soil, } \\
20 \mathrm{~m} \text { from foot slope, ephemeral gully area }\end{array}$ & 1180 & SW & $25^{\circ}-35^{\circ}$ \\
\hline D4 & $36^{\circ} 05.460^{\prime} \mathrm{N} ; 109^{\circ} 8.884^{\prime} \mathrm{E}$ & $\begin{array}{l}\text { Ziwuling experimental station, bare soil, } \\
10 \mathrm{~m} \text { from foot slope, gully area }\end{array}$ & 1154 & SW & $35^{\circ}-40^{\circ}$ \\
\hline
\end{tabular}


Table 2 Heterogeneity of the mean weighted diameter among the sampling sites (inter-site heterogeneity) for the fast wetting test, the slow wetting test, the stirring test and the mean of the three tests. Mean of the MWD corresponds to the mean of five

\begin{tabular}{rcccccccccc}
\multicolumn{1}{c}{ MWD of the crust } & \multicolumn{4}{c}{ MWD of the sub-crust } \\
\hline Stability test & $\begin{array}{c}\text { Min. } \\
\text { /mm }\end{array}$ & $\begin{array}{c}\text { Max. } \\
/ \mathbf{m m}\end{array}$ & $\begin{array}{c}\text { Mean } \\
/ \mathbf{m m}\end{array}$ & $\begin{array}{c}\boldsymbol{\sigma}^{\mathbf{a}} \\
/ \mathbf{m})\end{array}$ & $\mathbf{C V}^{\mathbf{b}}$ & $\begin{array}{c}\text { Min. } \\
/ \mathbf{m m}\end{array}$ & $\begin{array}{c}\text { Max. } \\
/ \mathbf{m m}\end{array}$ & $\begin{array}{c}\text { Mean } \\
/ \mathbf{m m}\end{array}$ & $\begin{array}{c}\boldsymbol{\sigma} \\
\mathbf{m m}\end{array}$ & $\mathbf{C V}$ \\
\hline Fast wetting & 0.20 & 1.62 & 0.98 & 0.41 & 0.42 & 0.13 & 0.95 & 0.36 & 0.18 & 0.51 \\
Slow wetting & 0.41 & 2.22 & 1.47 & 0.52 & 0.36 & 0.22 & 1.93 & 0.97 & 0.52 & 0.54 \\
Stirring & 0.29 & 1.77 & 1.14 & 0.41 & 0.39 & 0.23 & 1.23 & 0.69 & 0.27 & 0.39 \\
Mean of the 3 tests & 0.33 & 2.04 & 1.20 & 0.44 & 0.37 & 0.23 & 1.42 & 0.68 & 0.32 & 0.47 \\
\hline
\end{tabular}

plots with two replicates each, $\mathrm{n}=10$.

$603{ }^{\mathrm{a}} \sigma$ : standard deviation; ${ }^{\mathrm{b}} \mathrm{CV}$ : coefficient of variation. 
Table 3 Heterogeneity of the difference in mean weighted diameter between crust

605 and sub-crust (a) among the sampling sites (inter-site heterogeneity) for all stability

606 tests, and (b) for each site (intra-site heterogeneity) for the mean of the three stability

607 tests. Mean of the MWD corresponds to the mean of five plots with two replicates

608 each, $\mathrm{n}=10$.

609

(a)

Difference in MWD between crust and sub-crust

\begin{tabular}{|c|c|c|c|c|c|}
\hline Stability test & $\begin{array}{l}\text { Min. } \\
\text { / } \mathbf{m m}\end{array}$ & $\begin{array}{l}\text { Max. } \\
\text { / mm }\end{array}$ & $\begin{array}{l}\text { Mean } \\
/ \mathrm{mm}\end{array}$ & $\begin{array}{c}\sigma \\
/ \mathrm{mm}\end{array}$ & $\mathrm{CV}$ \\
\hline Fast wetting & 0.10 & 1.04 & 0.62 & 0.35 & 0.56 \\
\hline Slow wetting & 0.24 & 1.03 & 0.50 & 0.30 & 0.60 \\
\hline Stirring & 0.00 & 0.81 & 0.45 & 0.32 & 0.71 \\
\hline Mean of the 3 tests & 0.16 & 0.93 & 0.46 & 0.28 & 0.60 \\
\hline
\end{tabular}

$610 \quad{ }^{\mathrm{a}} \sigma$ : standard deviation; ${ }^{\mathrm{b}} \mathrm{CV}$ : coefficient of variation.

(b)

Difference in MWD between crust and sub-crust

\begin{tabular}{rccccc}
\hline Site & $\begin{array}{c}\text { Min. } \\
/ \mathbf{m m}\end{array}$ & $\begin{array}{c}\text { Max. } \\
/ \mathbf{m m}\end{array}$ & $\begin{array}{c}\text { Mean } \\
/ \mathbf{m m}\end{array}$ & $\begin{array}{c}\boldsymbol{\sigma} \\
/ \mathbf{m m}\end{array}$ & $\mathbf{C V}$ \\
\hline $\mathbf{A}$ & 0.61 & 0.90 & 0.80 & 0.12 & 0.22 \\
$\mathbf{B}$ & 0.44 & 1.24 & 0.77 & 0.30 & 0.39 \\
$\mathbf{C}$ & 0.09 & 0.27 & 0.16 & 0.07 & 0.45 \\
D1 & 0.08 & 1.25 & 0.52 & 0.47 & 0.90 \\
D2 & 0.08 & 0.59 & 0.31 & 0.27 & 0.87 \\
D3 & 0.05 & 0.40 & 0.18 & 0.14 & 0.76 \\
D4 & 0.83 & 1.13 & 0.93 & 0.15 & 0.16 \\
\hline
\end{tabular}

612

${ }^{\mathrm{a}} \sigma$ : standard deviation; ${ }^{\mathrm{b}} \mathrm{CV}$ : coefficient of variation. 
613 Table 4 Correlations (Pearson's coefficient) between aggregate stability and standard

614 soil properties (a) for the crust and (b) for the sub-crust.

(a)

\begin{tabular}{cccccccc} 
MWD & $\begin{array}{c}\text { Water } \\
\text { content }\end{array}$ & $\begin{array}{c}\text { Organic } \\
\text { matter }\end{array}$ & CEC & pH & $\begin{array}{c}\text { Clay } \\
\text { content }\end{array}$ & $\begin{array}{c}\text { Silt } \\
\text { content }\end{array}$ & $\begin{array}{c}\text { Sand } \\
\text { content }\end{array}$ \\
\hline Fast wetting & $\mathbf{0 . 3 5}$ & $\mathbf{0 . 5 0}$ & $\mathbf{0 . 5 0}$ & 0.11 & 0.08 & -0.31 & 0.21 \\
Slow wetting & $\mathbf{0 . 3 2}$ & $\mathbf{0 . 5 7}$ & $\mathbf{0 . 4 6}$ & 0.22 & 0.09 & -0.18 & 0.11 \\
Stirring & $\mathbf{0 . 4 5}$ & $\mathbf{0 . 4 2}$ & $\mathbf{0 . 5 6}$ & 0.20 & 0.14 & -0.16 & 0.06 \\
Mean of the three tests & $\mathbf{0 . 3 6}$ & $\mathbf{0 . 5 2}$ & $\mathbf{0 . 5 2}$ & 0.18 & -0.10 & -0.22 & 0.13 \\
\hline
\end{tabular}

$616 \mathrm{n}=35 ; \alpha=5 \%: r=0.32$

617 bold $=$ significant at the $5 \%$ level

(b)

\begin{tabular}{cccccccc} 
MWD & $\begin{array}{c}\text { Water } \\
\text { content }\end{array}$ & $\begin{array}{c}\text { Organic } \\
\text { matter }\end{array}$ & CEC & pH & $\begin{array}{c}\text { Clay } \\
\text { content }\end{array}$ & $\begin{array}{c}\text { Silt } \\
\text { content }\end{array}$ & $\begin{array}{c}\text { Sand } \\
\text { content }\end{array}$ \\
\hline Fast wetting & -0.11 & $\mathbf{0 . 5 1}$ & $\mathbf{0 . 4 4}$ & 0.19 & 0.12 & 0.09 & -0.07 \\
Slow wetting & -0.17 & $\mathbf{0 . 5 6}$ & $\mathbf{0 . 4 4}$ & $\mathbf{0 . 4 1}$ & 0.04 & -0.12 & 0.11 \\
Stirring & -0.05 & 0.22 & $\mathbf{0 . 4 6}$ & $\mathbf{0 . 4 7}$ & 0.28 & 0.29 & -0.29 \\
Mean of the three tests & -0.13 & $\mathbf{0 . 4 9}$ & $\mathbf{0 . 4 8}$ & $\mathbf{0 . 4 1}$ & 0.13 & 0.03 & -0.04 \\
\hline
\end{tabular}

$\mathrm{N}=35 ; \alpha=5 \%: r=0.32$

bold $=$ significant at the $5 \%$ level 
620 Table 5 Correlations (Pearson's coefficient) between the differences in aggregate stability between crust and sub-crust and the standard soil

621 properties.

\begin{tabular}{|c|c|c|c|c|c|c|c|c|c|c|c|c|c|c|c|c|c|c|c|c|c|}
\hline \multirow{2}{*}{$\begin{array}{c}\text { Difference in } \\
\text { MWD }\end{array}$} & \multicolumn{3}{|c|}{ Water content } & \multicolumn{3}{|c|}{ Organic matter } & \multicolumn{3}{|c|}{ CEC } & \multicolumn{3}{|c|}{ pH } & \multicolumn{3}{|c|}{ Clay content } & \multicolumn{3}{|c|}{ Silt Content } & \multicolumn{3}{|c|}{ Sand content } \\
\hline & $\mathrm{C}$ & $\mathrm{U}$ & $\mathrm{C}-\mathrm{U}$ & $\mathrm{C}$ & $\mathrm{U}$ & $\mathrm{C}-\mathrm{U}$ & $\mathrm{C}$ & $\mathrm{U}$ & $\mathrm{C}-\mathrm{U}$ & $\mathrm{C}$ & $\mathrm{U}$ & $\mathrm{C}-\mathrm{U}$ & $\mathrm{C}$ & $\mathrm{U}$ & $\mathrm{C}-\mathrm{U}$ & $\mathrm{C}$ & $\mathrm{U}$ & $\mathrm{C}-\mathrm{U}$ & $\mathrm{C}$ & $\mathrm{U}$ & $\mathrm{C}-\mathrm{U}$ \\
\hline Fast wetting & 0.40 & 0.29 & 0.30 & 0.40 & 0.27 & 0.29 & 0.45 & 0.45 & -0.16 & 0.04 & 0.16 & 0.09 & -0.07 & 0.20 & -0.21 & -0.46 & -0.26 & -0.23 & 0.37 & 0.16 & 0.23 \\
\hline Slow wetting & 0.32 & 0.42 & 0.09 & 0.18 & -0.01 & 0.42 & 0.12 & 0.15 & -0.10 & -0.19 & -0.07 & -0.11 & -0.21 & 0.25 & -0.35 & -0.22 & -0.04 & -0.25 & 0.23 & -0.06 & 0.36 \\
\hline Stirring & 0.40 & 0.26 & 0.32 & 0.40 & 0.29 & 0.29 & 0.35 & 0.33 & -0.07 & -0.01 & -0.28 & -0.06 & -0.19 & 0.09 & -0.21 & -0.48 & -0.32 & -0.16 & 0.42 & 0.23 & 0.19 \\
\hline $\begin{array}{l}\text { Mean of the } \\
\text { 3tests }\end{array}$ & 0.36 & 0.30 & 0.26 & 0.34 & 0.19 & 0.37 & 0.33 & 0.33 & -0.12 & -0.06 & 0.05 & -0.10 & -0.17 & 0.20 & -0.28 & -0.41 & 0.22 & -0.23 & 0.36 & 0.11 & 0.28 \\
\hline
\end{tabular}

622

$623 \mathrm{C}=$ crust; $\mathrm{U}=$ sub-crust; $\mathrm{C}-\mathrm{U}=$ difference in soil property value between the crust and the sub-crust. $\mathrm{N}=35 ; \alpha=5 \%: \underline{\mathrm{r}}=0.32$

624 Bold $=$ significant at the $5 \%$. 
625

List of Figures

626 Figure 1 Location of the study sites.

627 Figure 2 Aggregate stability of crust and sub-crust for (a) fast wetting, (b) slow

628 wetting, (c) stirring tests and (d) the mean of the three tests for all sites. Each MWD

629 corresponds to the mean of five plots with two replicates each, $n=10$. Bars represent

630 standard errors.

631 Small letters above the bars correspond to paired comparisons between crust and sub-

632 crust for a given site, and paired comparison between sites (Wilcoxon test, $\alpha=5 \%$ ).

633 VS: very stable; S: stable; M: medium; U: unstable; VU: very unstable (Le

634 Bissonnais, 1996).

635 Figure 3 Crust and sub-crust contents in (a) clay, (b) silt, and (c) sand for all sites.

636 The data from each site correspond to the mean of five plots with two replicates each,

$637 n=10$. Bars represent standard errors. Small letters above the bars correspond to paired

638 comparisons between crust and sub-crust for a given site, and paired comparison

639 between sites (Wilcoxon test, $\alpha=5 \%$ ).

640 Figure 4 Crust and sub-crust values for (a) organic matter content, (b) CEC and

641 (c) $\mathrm{pH}$, for all sites. The data from each site correspond to the mean of five plots with

642 two replicates each, $n=10$. Bars represent standard errors.Letters above the bars

643 correspond to paired comparisons between crust and sub-crust for a given site, and 644 paired comparison between sites (Wilcoxon test, $\alpha=5 \%$ ). 


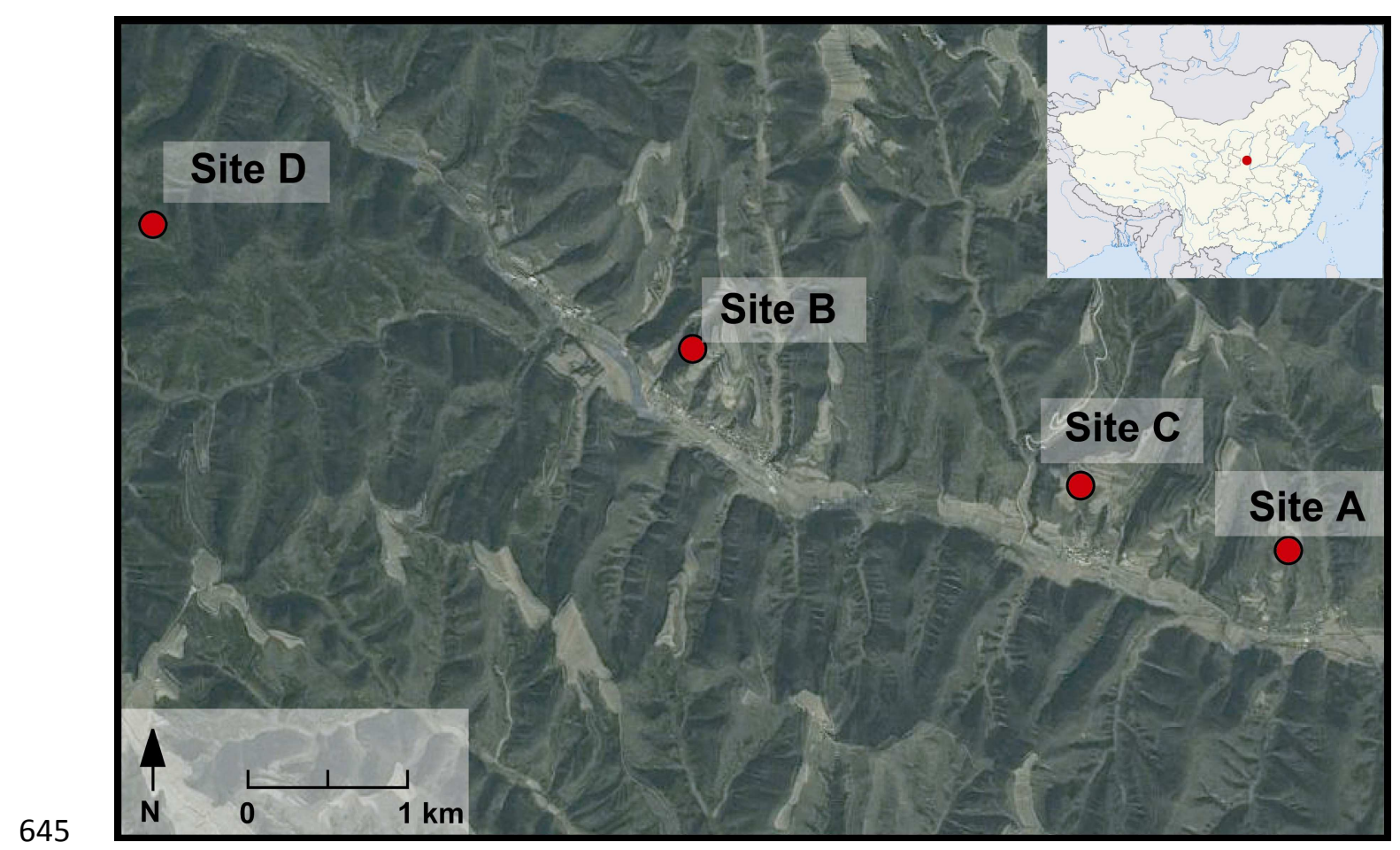

646 Figure 1 Location of the study sites. 

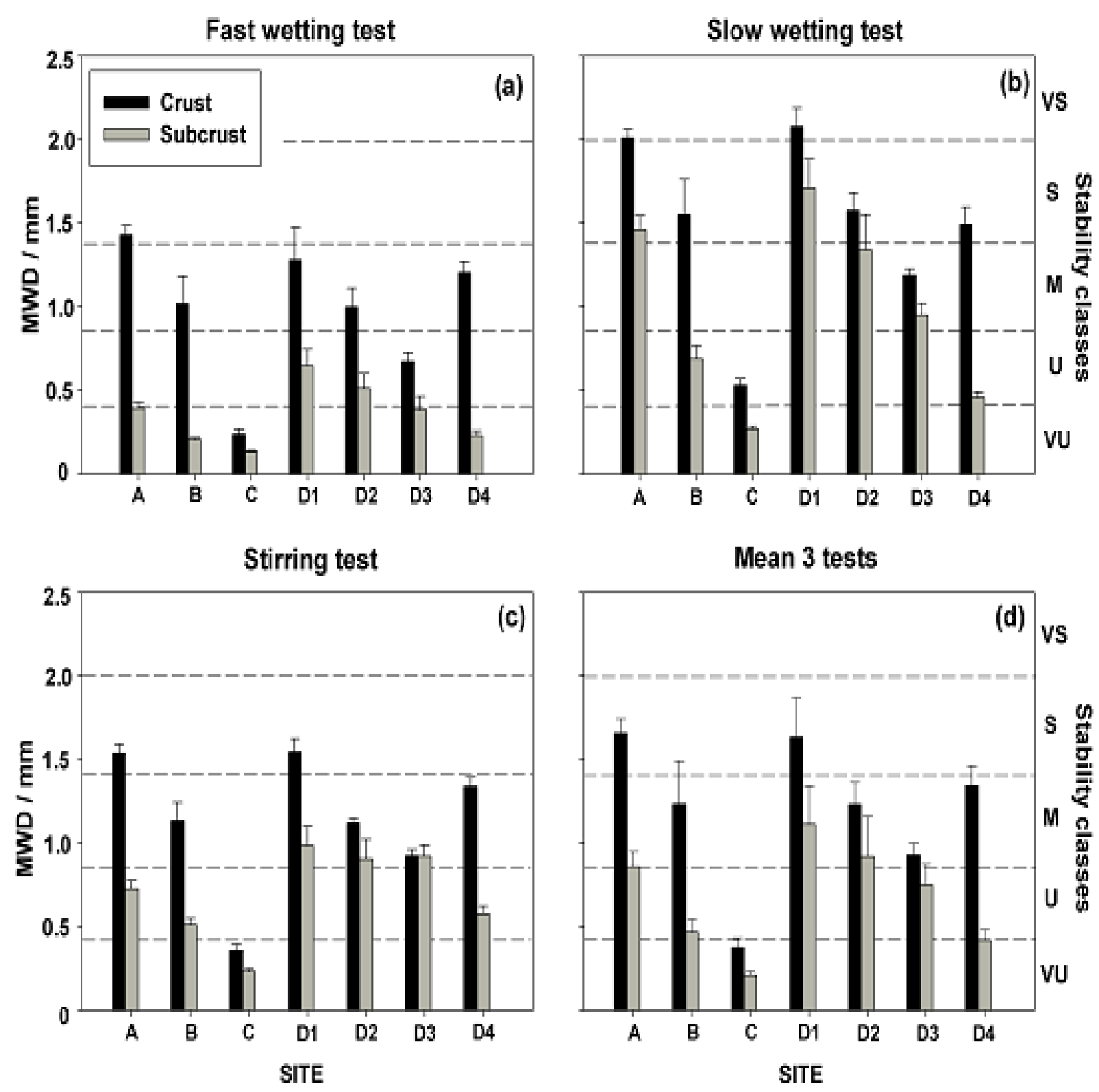

647

Figure 2 Aggregate stability of crust and sub-crust for (a) fast wetting, (b) slow

649 wetting, (c) stirring tests and (d) the mean of the three tests for all sites. Each MWD

650 corresponds to the mean of five plots with two replicates each, $n=10$. Bars represent

651 standard errors.

652 Small letters above the bars correspond to paired comparisons between crust and sub-

653 crust for a given site, and paired comparison between sites (Wilcoxon test, $\alpha=5 \%$ ).

654 VS: very stable; S: stable; M: medium; U: unstable; VU: very unstable (Le

655 Bissonnais, 1996). 


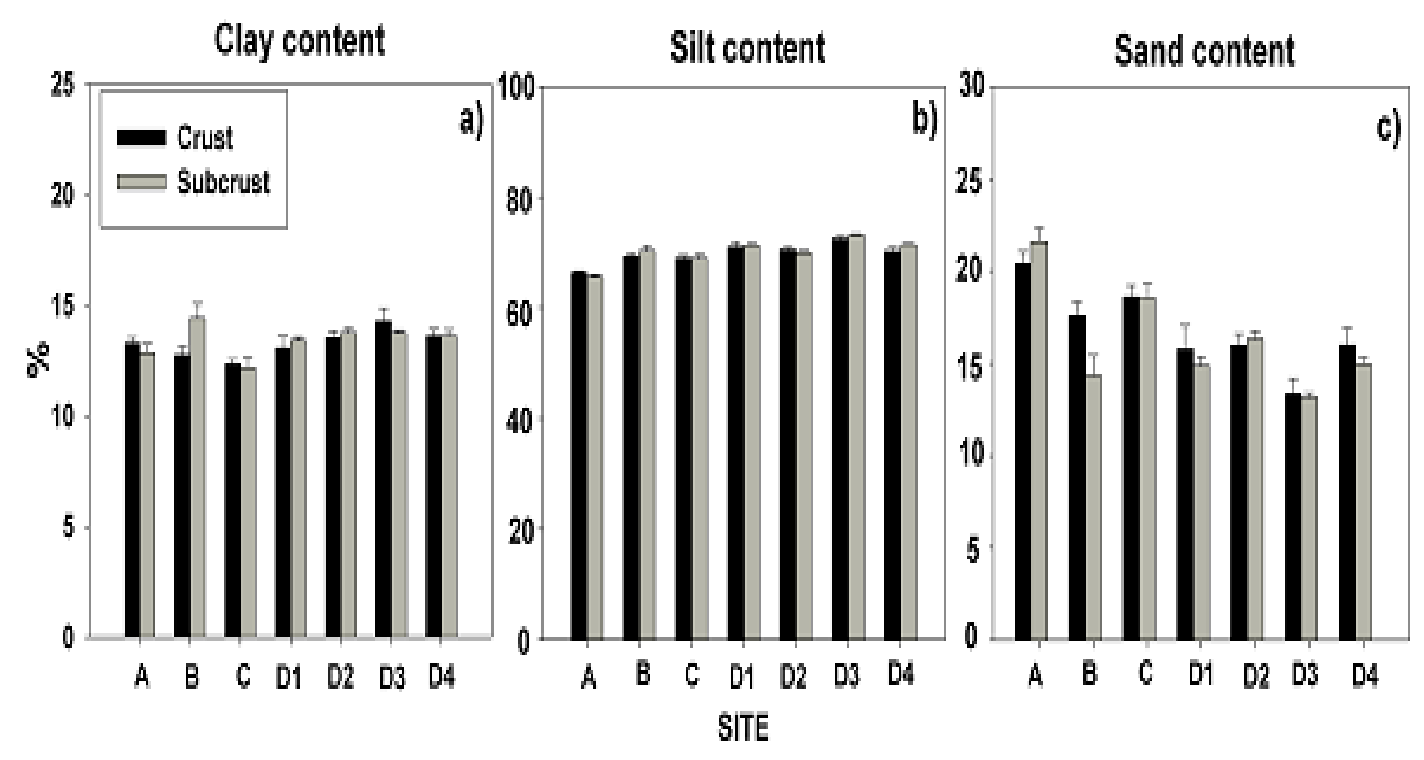

658 Figure 3 Crust and sub-crust contents in (a) clay, (b) silt, and (c) sand for all sites.

659 The data from each site correspond to the mean of five plots with two replicates each,

$660 \mathrm{n}=10$. Bars represent standard errors. Small letters above the bars correspond to paired

661 comparisons between crust and sub-crust for a given site, and paired comparison

662 between sites (Wilcoxon test, $\alpha=5 \%$ ). 

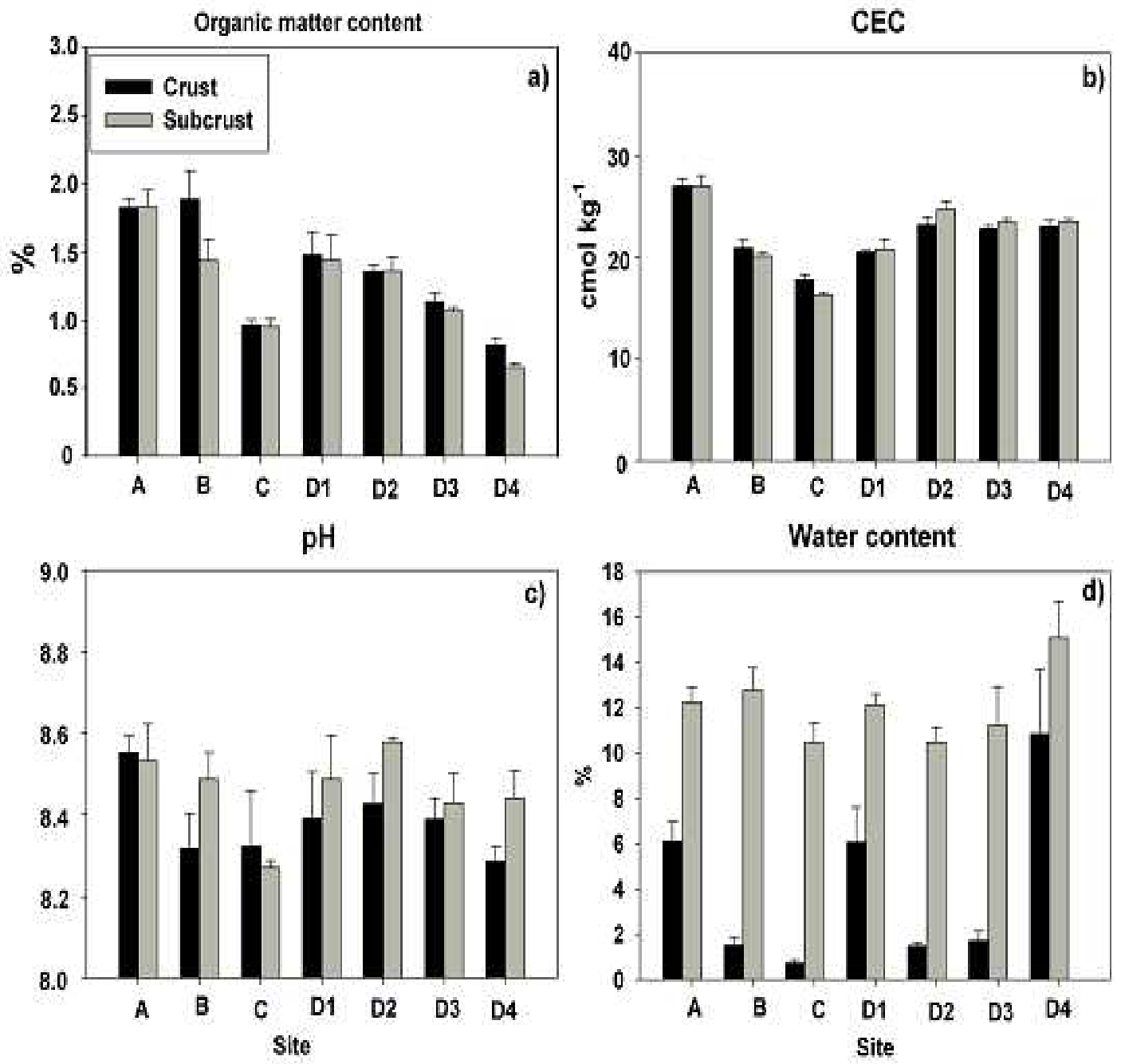

Figure 4 Crust and sub-crust values for (a) organic matter content, (b) CEC and (c) $\mathrm{pH}$, for all sites. The data from each site correspond to the mean of five plots with

668 two replicates each, $n=10$. Bars represent standard errors.Letters above the bars correspond to paired comparisons between crust and sub-crust for a given site, and

670 paired comparison between sites (Wilcoxon test, $\alpha=5 \%$ ).

671 